\title{
IMPLEMENTASI PENDEKATAN CONTEXTUAL TEACHING AND LEARNING DALAM PEMBELAJARAN AKIDAH AKHLAK DI MADRASAH IBTIDAIYAH
}

\author{
H. Moh. Masnun* \\ *Dosen Jurusan PGMI FITK IAIN Syekh Nurjati Cirebon
}

\begin{abstract}
ABSTRAK
Salah satucara untuk membangkitkan aktivitas peserta didik dalam proses pembelajaran adalah dengan mengganti cara/pendekatan pembelajaran yang selama ini tidak diminati lagi oleh peserta didik, seperti pembelajaran yang dilakukan dengan ceramah dan tanya-jawab, pendekatan pembelajaran ini membuat peserta didik jenuh dan tidak kreatif. Suasana belajar mengajar yang diharapkan adalah menjadikan peserta didik sebagai subjek yang berupaya menggali sendiri, memecahkan sendiri masalah-masalah dari suatu konsep yang dipelajari, sedangkan guru lebih banyak bertindak sebagai motivator dan fasilitator. Situasi belajar yang diharapkan disini adalah peserta didik yang lebih banyak berperan (kreatif).

Pendekatan pembelajaran kontekstual merupakan konsep belajar yang membantu guru mengaitkan antara materi yang diajarkan dengan situasi dunia nyata peserta didik dan mendorong peserta didik membuat hubungan antara pengetahuan yang dimilikinya dengan penerapannya dalam kehidupan mereka sebagai anggota keluargadan masyarakat. Dengan konsep itu ,hasil pembelajaran diharapkan lebih bermakna bagi peserta didik.
\end{abstract}

Kata Kunci : Pembelajaran Kontekstual, Aktifitas, Peserta Didik 


\section{A. Pendahuluan}

Dalam bidang pendidikan, pemerintah selalu berusaha untuk meningkatkan kualitas pendidikan dengan berbagai cara seperti mengganti kuikulum, meningkatkan kualitas guru melalui penataran-penataran atau melanjutkan seklah ketingkat yang lebih tinggi, memberi dana Bantuan Operasional Sekolah (BOS)dan sebagainya. Sesuaidengan Undang-undang Nomor 20 tahun 2003 tentang Sistem Pendidikan Nasional, Pasal3menyatakan bahwa:

PendidikanNasionalberfungsimengembangkan kemampuandan membentuk watak serta peradaban bangsa yang bermartabat dalam rangka mencerdaskan kehidupan bangsa, bertujuan untuk berkembangnya potensi peserta didik agar menjadi manusia yang bertakwa kepada Tuhan Yang Maha Esa, berakhlak mulia, sehat, berilmu, cakap, kreatif, mandiri dan menjadi warga Negara yang demokratis serta bertanggung jawab.

Dengan memperhatikan isi dari Undang-undang Nomor20 tahun 2003 tentang Sistem Pendidikan Nasional tersebut, penulis berpendapat bahwa tugas seorang pendidik memang berat, sebab kemajuan suatu bangsa ditentukan oleh keberhasilan pendidikan dari bangsa itu sendiri. Jika seorang guru atau pendidik tidak berhasil mengembangkan potensi peserta didik secara utuh maka Negara itu tidak akan maju, sebaliknya jika guru atau pendidik berhasil mengembangkan potensi peserta didik secara utuh, maka terciptalah manusia yang cerdas, terampil, dan berkualitas. Menurut Sanjaya(2007:19),peran guru adalah: "Sebagai sumber belajar, fasilitator, pengelola, demonstrator, pembimbing, dan evaluator". Sebagai motivator guru harus mampu membangkitkan motivasi peserta didik agar aktivitas peserta didik dalam proses pembelajaran berhasil dengan baik.

Salah satucara untuk membangkitkan aktivitas peserta didik dalam proses pembelajaran adalah dengan mengganti cara/pendekatan pembelajaran yang 
selama ini tidak diminati lagi oleh peserta didik, seperti pembelajaran yang dilakukan dengan ceramah dan tanya-jawab, pendekatan pembelajaran ini membuat peserta didik jenuh dan tidak kreatif. Suasana belajar mengajar yang diharapkan adalah menjadikan peserta didik sebagai subjek yang berupaya menggali sendiri, memecahkan sendiri masalah-masalah dari suatu konsep yang dipelajari, sedangkan guru lebih banyak bertindak sebagai motivator dan fasilitator. Situasi belajar yang diharapkan disini adalah peserta didik yang lebih banyak berperan (kreatif).

Berdasarkan pengalaman yang pernah penulis hadapi didalam proses pembelajaran aqidah akhlak yang tidak aktif maka penulis berusaha mencarikan pendekatan pembelajaran lain, sehingga pembelajaran lebih bermakna dan lebih berkualitas. dalam kontek sini penulis mencoba pendekatan pembelajaran kontekstualatau Contextual Teachingand Learning.

Pendekatan pembelajaran kontekstual merupakan konsep belajar yang membantu guru mengaitkan antara materi yang diajarkan dengan situasi dunia nyata peserta didik dan mendorong peserta didik membuat hubungan antara pengetahuan yang dimilikinya dengan penerapannya dalam kehidupan mereka sebagai anggota keluargadan masyarakat. Dengan konsep itu ,hasil pembelajaran diharapkan lebih bermakna bagi peserta didik.

Dalam kelas kontekstual, tugas guru adalah membantu pesertadidik mencapai tujuannya. Tugas guru mengelola kelas sebagai sebuah tim yang bekerja bersama untuk menemukan sesuatu yang baru bagi anggota kelas (pesertadidik). Sesuatu yang baru dating dari menemukan sendiri bukan dari apa kataguru. Begitulah peran guru dikelas yang dikelola dengan pendekatan kontekstual Teaching and Learning.

\section{B. Kajian Teori}

\section{Hakikat Pembelajaran}


Kegiatan pendidikan disekolah tidak lepas dari kegiatan belajar para pesert adidiknya. Kegiatan belaja rmerupakan suatu proses untuk mendaptkan hasil belajar. Hasil belajar akan ditentukan keberhasilannya oleh proses belajar yang dilakukan. Pengertian belajar banyak dikemukan oleh para ahli psikologi pendidikan,yaitu sebagaiberikut:

Belajar menurut Dimyati dan Mujiono (2002:10). "Belajarmerupakan kegiatan yang kompleks, hasil belajar berupa kapabilitas. Setelah belajar orang memiliki keterampilan, pengetahuan, sikap dan nilai. Timbulnya kapabilitas itu adalah berasal dari stimulasi yang berasal dari lingkungan dan proses kognitif yang merubah sifat stimulasi lingkungan melewati pengolahan informasi, menjadi kapabilitas baru”. Menurut Ruseffendi (1994:63) pembelajaran adalah “upaya mempersiapkan peserta didik untuk menjadi warga masyarakat yang baik dan meningkatkan kemampuan peserta didik berkomunikasi secara lisan dan tertulis".

Dari pendapat diatas dapat disimpulkan bahwa pembelajaran merupakan suatu kombinasi yang tersusun mulai dari unsur-unsur manusiawi, baik materil, fasilitas untuk meningkatkan kemampuan peserta didik dalam berkomunikasi dan menjadi warga masyarakat yang baik.

\section{Pengertian Pendekatan Contekstual Teaching and Learning}

Pendekatan Pembelajaran dapat diartikan sebagai kerangka konseptual yang melukiskan prosedur yang sistematis dalam mengorganisasikan pengalaman belajar untuk mencapai tujuan belajar tertentu, dan berfungsi sebagai pedoman bagi para perancang pembelajaran dan para pengajar dalam merencanakan dan melaksanakan aktivitas pembelajaran. Dengan demikian, aktivitas pembelajaran benar-benar merupakan kegiatan bertujuan yang tertata secara sistematis.

Pembelajaran kontekstual atau Contextual Teaching and Learning menurut Karli dan Margaretha(2002:150 )“merupakan suatu konsepsi yang membantu 
guru mengkaitkan konten mata pelajaran dengan situasi dunia nyata dan memotivasi peserta didik membuat hubungan antara pengetahuan dan penerapannya dalam kehidupan mereka sebagai anggota keluarga, warganegara, dan tenagakerja”.

\section{Langkah-langkah Pendekatan Contextual Teaching andLearning dalam} Pembelajaran Aqidah Akhlak

Pendekatan kontekstual sebagai suatu pendekatan pembelajaran yang memfasilitasi kegiatan belajar peserta didik untuk mencari, mengolah, dan menemukan pengalaman belajar yang lebih bersifat kongkrit (terkait dengan kehidupan nyata) melalui pelibatan aktivitas belajar mencoba melakukan dan mengalami sendiri(learningbydoing). Dengan demikian pembelajaran tidak sekedar dilihat dari sisi produk, akan tetapi yang terpenting adalah proses. Oleh karena itu tugas guru adalah menyiasati strategi pembelajaran bagaimana yang dipandang lebih efektif dalam membimbing kegiatan belajar peserta didik agar dapat menemukan apa yang menjadi harapannya.

Sebelum melaksanakan pembelajaran dengan menggunakan pendekatan Contextual Teaching and Learning, tentu saja terlebih dahulu guru harus membuat disain/scenario pembelajarannya, sebagai pedoman umum dan sekaligus sebagai alat control dalam pelaksanaannya. Pada intinya pengembangan setiap komponen Contextual Teaching and Learning dalam

pembelajaran dapat dilakukan melalui langkah-langkah sebagaimana dikemukakan Nurhadi (2003:28) sebagai berikut:

1. Mengembangkan pemikiran peserta didik untuk melakukan kegiatan belajar lebih bermakna, apakah dengan cara bekerja sendiri, menemukan sendiri, dan mengkontruksi sendiri pengetahuan dan keterampilan baru yang harus akan dimilikinya. 
2. Melaksanakans ejauh mungkin kegiatan inquiry untuk semua topic yang diajarkan.

3. Mengembangkan sifat ingin tahu peserta didik melalui memunculkan pertanyaan-pertanyaan.

4. Menciptakan masyarakat belajar, seperti melalui kegiatan kelompok, tanyajawab dan lain sebagainya.

5. Membiasakan anak untuk melakukan refleksi dari setiap kegiatan pembelajaran yang telah dilakukan.

6. Melakukan penilaian secara objektif, yaitu menilai kemampuan yang Sebenarnya pada setiap peserta didik.

Adapun tujuh komponen Contextua ITeaching and Learning menurut

Sanjaya (2007:263) adalah sebagai berikut:

a. Konstruktivisme(Contructivisme)

b. Menemukan(Inquiry)

c. Bertanya(Questioning)

d. MasyarakatBelajar(LearningCommunity)

e. Pendekatanan(Pendekatanling)Refleksi(Reflection)

f. PenilaianSebenarnya(AuthenticAssessment)

4. PendekatanEvaluasiPembelajaranContextual Teaching and Learning

Evaluasi artinya penilaian terhadap tingkat keberhasilan peserta didik mencapai tujuan yang telah ditetapkan dalam sebuah program. Padanankata evaluasi adalah assessment menurut Syah (1995:141) berarti "proses penilaian untuk menggambarkan prestasi yang dicapai seorang peserta didik sesuai dengan criteria yang telah ditetapkan ".Evaluasi yang berarti pengungkapan dan pengukuran hasil belajar itu pada dasarnya merupakan proses penyusunan deskripsi peserta didik, baik secara kuantitatif maupun kualitatif yang memiliki tujuan sebagai berikut:

1. Untuk mengetahui tingkat kemajuan yang telah dicapai oleh peserta didik. 
2. Untuk mengetahui kedudukan seorang peserta didik dalam kelompok kelasnya.

3. Untuk mengetahui tingkat usaha yang dilakukan peserta didik dalam belajar.

4. Untuk mengetahui hingga sejauh mana peserta didik telah mendayagunakan kapasitas kognitifnya (kemampuan kecerdasan) untuk keperluan belajar.

5. Untuk mengetahui tingkat daya guna dan hasil guna metode mengajar yang telah digunakan guru dalam proses belajar mengajar.

Dalam pembelajaran Contextual Teaching and Learning, evaluasi dapat dilakukan melalui penilaian autentik (Authentic Assessment). Penilaian autentik menurut Nurhadi (2003:95) adalah: Suatu istilah/terminology yang diciptakan untuk menjelaskan berbagai metode penilaian alternative yang memungkinkan peserta didik dapat mendemonstrasikan kemampuannya dalam menyelesaikan tugas-tugas dan menyelesaikan masalah. Sekaligus, mengekspresikan pengetahuan dan keterampilannya dengan cara mensimulasikan situasi yang dapat ditemui didalam dunia nyata diluar lingkungan sekolah. Dalam hal ini adalah simulasi yang dapat mengekspresikan prestasi peserta didik yang ditemui didalam praktek dunia nyata.

\section{KonsepPembelajaranAqidahAkhlak}

a. Pengertian dan Tujuan Pembelajaran Akidah Akhlak

Istilah "Akhlak" berasal dari bahasa Arab, jama 'dari" Khuluqun”, secara lughat dapat diartikan sebagai budi pekerti, perangai, tingkah laku atau tabiat. Kalimat itu mengandung segi-segi kesesuaian dengan perkataan "Khalqun" yang berarti kejadian dan sangat erat hubungannya dengan "Khaliq" yang berarti pencipta, dan "Makhluq" yang berarti suatu objek yang diciptakan.

Menurut Moh Rifai (1994:35) "Kata akhlak walaupun diambil dari bahasa Arab, tetapi kata seperti itu tidak ditemukan dalam Al-Qur'an. Dan yang 
ditemukan hanyalah bentuk tunggal kata tersebut yaitu "Khuluq" yang tercantum dalam Al-Qur'an surat Al-Qalam ayat 4. Perumusan pengertian "Akhlak" timbul sebagai suatu bentuk atau pola komunikasi antar akhalik dengan makhluk dan antara makhluk dengan makhluk.

Dari uraian diatas, penulis dapat mengambil ikhtisar bahwa pada hakikatnya akhlak merupakan suatu kondisi atau sifat yang telah meresap dalam jiwa dan menjadi kepribadian sehingga dari itu timbul berbagai macam perbuatan dengan cara spontan dan mudah tanpa dibuat-buat tanpa memerlukan pemikiran. Apabila dari kondisi tersebut menimbulkan suatu perbuatan yang baik dan terpuji, maka menurut pandangan syari'at Islam dan akal pikiran dinamakan dengan budi pekerti yang mulia, dan sebaliknya apabila melahirkan perbuatan yang buruk, maka disebut budi pekerti yang tercela.

b. FungsidanRuangLingkupPembelajaranAkidahAkhlak

Menurut Moh Rifai (1994:47) fungsi pembelajaran akidah akhlak di Madrasah Ibtidaiyah sebagaimana tercantum dalam Kurikulum Tingkat Satuan Pendidikan adalah sebagai berikut:

1) Pengembangan, yaitu meningkatkan keimanan dan ketakwaan siswa kepada Allah SWT yang telah ditanamkan dalam lingkungan keluarga.

2) Perbaikan, yaitu memperbaiki kesalahan dalam keyakinan, kesalahan dalam pemahaman, dan kesalahan dalam pengamalan ajaran agama Islam dalam kehidupan sehari-hari.

3) Pencegahan, yaitu untuk menjaga hal-hal negative dari lingkungan dan budaya yangmenghambatperkembangandirinya.

4) Pengajaran, yaitu menyampaikan berbagai pengetahuan keimanan dan akhlak.

5. Faktor-faktoryang Memengaruhi Pembelajaran Akidah Akhlak 
Ada beberapa factor yang memengaruhi pendidikan akidah akhlak, antara lain yaitu ;
a. LingkunganKeluarga
b. LingkunganSosial(Masyarakat danTetangga)
c. LingkunganAlam

Hasil pengamatan yang dilakukan observer tentang rencana pelaksanaan pembelajaran yang dilakukan peneliti, maka hasildari proses pembuatan perencanaan pembelajaran yang dilakukan peneliti pada siklus I belum mencapai nalai kategori baik, jadi masih perlu ditingkatkan lagi dari aspekaspek penilaian tertentu. Untuk rencana pembelajaran pada siklus II juga masih termasuk kategori sedang, jadi masih perlu ditingkatkan lagi dari aspek-aspek penilaian tertentu. Pada rencana pembelajaran siklus III nilai mencapai kategori baik dan niali yang diperoleh pun memuaskan kepada peneliti serta sesuai dengan tujuan pembelajaran yang diharapkan dari materi yang diberikan. Hasil rekapitulasi dari siklusI, siklusII dan siklusII dalam penyusunan perencanaan pembelajaran, perbandingannya dapat dilihat dari tabel4.13berikut:

$\mathrm{Tab}$

el13

RekapitulasiNilaiPenyusunanPerencanaanPembelaj aran

\begin{tabular}{|c|c|c|c|}
\hline No. & Siklus & Rata-rata & Prosentase \\
\hline 1. & I & 3,17 & $79,17 \%$ \\
\hline 2. & II & 3,36 & $84 \%$ \\
\hline 3. & III & 3,81 & $95,25 \%$ \\
\hline
\end{tabular}


Rekapitulasi nilai dalam penyusunan perencanaan pembelajaran pada data tabel diatas, menunjukan adanya perubahan nilai prosentase. Maka dapat disimpulkan bahwa penyusunan perencanaan pembelajaran aqidah akhlak dengan menggunakan pendekatan pembelajaran Contextual Teaching Learning sebagai sumber belajar.

\section{F. Penutup}

Perencanaan Pembelajaran Aqidah Akhlak dengan menggunakan pendekatan pembelajaran Contextual Teaching Learning. Dari hasil penelitian perencanaan pembelajaran yang dilakukan oleh peneliti dari siklus kesiklus telah mengalami perubahan yang cukup signifikan terutama dalam merencanakan kegiatan inti pembelajaran yang sifatnya harus selalu ditingkatkan berdasarkan hasil refleksi dariakhir siklus pembelajaran. 


\section{DAFTARPUSTAKA}

Amin,Ahmad.1993. Etika(IlmuAkhlak).Jakarta:CV.BulanBintang.

Arikunto,Suharsimi.2008.PenelitianTindakan Kelas.Jakarta.BumiAksara.

DimyatidanMujiono.2002.BelajardanPembelajaran.Jakarta:RinekaCipta.

Haryati, Tati.2009.PembelajaranContextualDalamPembelajarandiSMP.

Ibrahim dan Sudjana Nana. 1989. Penelitiandan Penilain Pendidikan. Bandung: Sinar Baru dan Pusat Penelitian Pengajaran dan Pengembangan Ilmu Lembaga Penelitian IKIP Bandung.

Karli,dan Margaretha 2002. Implementasi KTSP dalam Model-model Pembelajaran. Bandung: Generasi Info Media.

Muslich,Mansur.2009.MelaksanakanPTK ItuMudah (ClassroomActionResearch) Pedoman Praktis Bagi Guru Profesional .Jakarta:PT Bumi Aksara.

Nurhadi.2003. PendekatanKontekstual.Jakarta:Depdiknas.

Pasaribu,I.L.dan Simandjuntak,B.1983.Proses BelajarMengajar.Bandung: Tarsito.

Purwanto,M.Ngalim.1998.Ilmu Pendidikan Teoretis dan Praktis. Bandung: PT. Remaja Rosdakarya

Rifai,Mohammad.1994.AkidahAkhlak.Semarang.CVWicaksana

Ruseffendi,E.T. 1994. Dasar-Dasar Penelitian Pendidikan dan Bidang Non Eksakta Lainnya. Semarang: IKIP Semarang.

Sanjaya, Wina. 2007. Strategi Pembelajaran (Berorientasi Standar ProsesPendidikan). Jakarta:Kencana

Syah,Muhibbin.1995. Psikologi Pendidikan Suatu Pendekatan Baru. Bandung:PT.Remaja Rosdakarya.

Sudjana,Nana. 2008.Dasar-Dasar Proses Belajar Mengajar. Bandung: Sinar Baru Algensindo.

Undang-undang Republik IndonesiaNo.20Tahun2003.Tentang"Sistem Pendidikan Nasional'.Jakarta:DewanPerwakilanRakyatRepublikIndonesia.

Wahab,AbdulAziz.2009. MetodedanModel-ModelMengajar.Bandung: Alfabeta. 